Универзитет у Београду, Факултет политичких наука, Београд

DOI 10.5937/kultura15492290

УДК 028:[316.774:004

$028 " 19 / 20 "$

категорија

\title{
EJEKTPOHCKA KHЫИГА
}

Сажетак: За разлику од многих текстова који су у протекле две деценије написани о крају штампане кьиге, овај рад се бави крајем електронске књиге. Последњи извештаји о губицима у електронском издаваштву показују да је штампана кьига поново преузела примат и сви су изгледи да ће тако остати. Међутим, успона и падова у е-издаваштву било је и раније; почетни оптимизам раних деведесетих замењен је озбиљним сумњама, да би појавом читача Киндл доило до тога да е-књига преузме примат. Насупрот овој, од самог почетка нестабилној ситуаиији на тржишту, е-књига је самом својом појавом изазвала толико полемика и прорицања будућности као ни један нови медиј. Многи су прогнозирали крај итампане кьиге, а тиме и крај читаве једне иивилизачије, други су најављивали дигиталну културу као потпуно нови начин живота, ретко ко се устезао да промене назове револуционарним, а већина се сложила да е-књиге имају многе предности. Да ли би се сада било ко усудио да нешто прогнозира.

Кључне речи: електронска књига, електронско издаваштво, штампана књига, Џон Томпсон

Ниједан нови медиј није изазвао самом својом појавом толико полемика и прорицања будућности, нити је имао такве успоне и падове на тржишту као електронска књига. ${ }^{1}$ Још од касних осамдесетих година прошлог века повела се прича о дигиталној будућности и могућим утицајима дигитализације на издавачку делатност, мада тада још увек нико није имао јасну представу о томе. Средином деведесетих појавиле су се бројне грозничаве спекулације о нестанку штампане књиге. Како је Интернет постао главна комуникацијска мрежа, многи су помислили да је могуће, ако не и вероватно, да ће штампана књига брзо отићи на исти начин као и

1 Овај рад представља допуњени и прилагођени део мастер тезе Дигитални Гутенберг (изазови и границе електронског издаваштва), одбрањене на Факултету политичких наука 2012. године 
грамофонска плоча и постати нешто мало више од колекционарског предмета.

Књига објављених на тему нестанка штампане књиге било је тако много да се, према Томпсону (John B. Thompson), може говорити о читавом малом поджанру у литератури, с тим што су оне, како Томпсон духовито примећује, објављене на старомодан начин, на папиру, што је показивало да њихови аутори нису изгубили смисао за иронију. ${ }^{2}$ Сви они бавили су се судбином књиге и читања у дигитално доба, а наслови су ишли од Гутенбергове елегије до Штампано је мртво. ${ }^{3}$ Крај књиге је био и честа тема новинских чланака, на пример, Robert Coover: The end of book, чланак објављен у Њујорк Тајмсу 21. јуна 1992, ${ }^{4}$ с тим што је у природи професије новинара да се нимало не устежу да објаве било чији крај, па ни крај књиге. Како пише Томпсон, новинари нарочито воле драматичне приче о крају цивилизације какву ми познајемо. „А и изгледа добро за наслов - Goodbye Gutenberg, и све то."'

У Србији су стручњаци такође посветили пажњу нестанку штампане књиге. Рецимо, Ковачевић пише да се много тога, у овом нашем свету који се убрзано мења, губи и нестаје, али мало шта се може упоредити са нестанком књиге. „У ситуацији када су смрти све више само појединачни догађаји без дубљег значаја и смисла”, пише Ковачевић, „само две смрти изазивају пажњу, страх или наду супротстављених табора. Најпре је полудели филозоф Ниче огласио да је умро Бог, а потом је, од средине прошлог века, најављена и смрт књиге."

Крај штампане књиге је најављиван у оквиру ширег контекста радова на тему дигиталне културе као потпуно новог начина живота. Компјутерисање се више не односи на компјутере, оно се бави начином живота, писао је Негропонт (Nicholas Negroponte) 1995. године у књизи Бити дигиталан, а Чарли Гир (Charlie Gere) пише о дигиталној култури у истоименом делу. Бројни аутори, који су се бавили издаваштвом уопште, били су склони да промене које су биле у

2 Thompson, J. B. (2010) Merchants of Culture, Cambridge: Polity, p. 315.

3 Исто, стр. 315.

4 Ковачевић, Н. (2010) О могућности и стварности - једно (не)аристотеловско читање е-књига, Култура бр. 129, Завод за проучавање културног развитка, Београд, стр. 32.

5 Thompson, J. B. (2010) Merchants of Culture, Cambridge: Polity, p. 321.

6 Ковачевић, Н. (2010) О могућности и стварности - једно (не)аристотеловско читање е-књига, Култура бр.129, Завод за проучавање културног развитка, Београд, стр. 21. 


\section{СОЊА ОЦИЋ}

току означе револуционарним. Вулф Д. фон Луцијус (Wulf D. von Lucius) прелазак на дигиталну публикацију назива револуцијом, јер је реч о ступању у „потпуно нови свет који отвара нове тржишне шансе", 7 а Барбије (Frédéric Barbier) заступа сличан став и каже да смо, укупно гледано, изашли из техничког система који је изумео Гутенберг и који се касније усавршавао.

Било да их назовемо револуционарним или не, сви аутори су се слагали да је основна тенденција ових промена била дематеријализација. У штампарству, после више од 5 векова (1450-1970) изашли смо из Гутенберговског система који се заснивао на окупљању ситних елемената (слова) пре њиховог отискивања. ${ }^{8}$ Процес је ишао од оловног, преко фотографског знака, до бинарног. Нумерички, тј. дигитални бит, заменио је онај фотон који је некада заменио олово и тако се завршио поступак дематеријализације штампарских техника. Даљи напредак у информатици (материјал, капацитет меморија, рачунарска обрада текста, објављивање уз помоћ рачунара), и нарочито развој Интернета, доводи до појаве електронског издаваштва.

Појавом електронске књиге, књига се дематеријализовала, али не само она; дематеријализација је нешто са чим се суочила читава култура. Културе је хиљадама година до сада била заснована на материјализацији трагова и знакова људског стваралаштва, док сада, у ери дигитализације, прелази у домен дематеријализације културних знакова, артефаката, трагова и објеката, запажа Угричић. ${ }^{9}$

У издавачкој индустрији деведесетих година прошлог века бројне консултантске куће су такође предвиђале да ће, кроз неколико година, електронске књиге истиснути штампане са тржишта. Таква очекивања су нарасла захваљујући почетном успеху издавачког експеримента електронским публиковањем романа Стивена Кинга Riding the Bullet. Роман се могао скинути по цени од два и по долара и резултат је био ван свих очекивања: за прва двадесет четири сата било је 400.000 преузимања. Овакви успеси довели су до нових улагања, али испоставило се да су преузимања других дела била веома ниска. То је према Томпсону била прва фаза у развоју електронског издаваштва.

7 Фон Луцијус, В. Д. (2011) Економика издавачке делатности, Београд: Клио, стр. 316.

8 Барбије, Ф. (2009) Историја књиге, Београд: Народна библиотека Србије и Клио, стр. 413.

9 Угричић, С. (2010) Адаптација, еволуција, револуција, Култура бр. 129, стр. 18. 
Другу фазу карактерисао је скептицизам у погледу могућности да дигитална револуција трансформише издавачку индустрију. Након петнаестак година улагања у електронско издаваштво, експериментисања и губљења новца, појавиле су се прве сумње. Један део тог скептицизма, према Томпсону, могао се објаснити као реакција на економску кризу 2000-2001. која је окончала период раста деведесетих. У многим издавачким кућама које су инвестирале значајне суме у експериментисање са новим технологијама, у неким случајевима радило се о читавим издањима електронских књига, превладало је ново осећање опреза. Био је то период, како пише Томпсон, сабирања губитака. ${ }^{10}$

Да би објаснили зашто електронске књиге у почетку нису примљене као што су многи очекивали, запослени у издаваштву наводили су четири разлога. Прво, тада је постојао проблем у хардверу, справи за читање која је првобитно била развијена и која је била скупа и незгодна за употребу. Друго, постојао је проблем у формату: било је мноштво формата који се нису прилагођавали различитим справама за читање. Као трећи проблем јавила су се ауторска права, јер је постојала недоумица коме се обратити за права да би се садржај одређене књиге појавио у електронском облику. Да ли права припадају издавачу или аутору и колико је новца потребно платити и коме? Већина уговора између аутора и издавача потписани су у време када није постојала идеја о електронском садржају књиге, тако да у уговору нема одредбе о томе ко контролише права. И као последњи разлог наводиле су се цене: издавачи и продавци одређују цене електронских издања, приближне ценама штампаних. То је делом био експеримент, а делом потврда чињенице да уштеда приликом испоруке садржаја књиге у електронској форми није тако велика као што су пионири електронског издаваштва тврдили. Трошкови као што су хонорари, маркетиншки трошкови, трошкови издавача, још увек су постојали. ${ }^{11}$ Почетком 2000-их само су ретки у издавачком свету веровали да електронска издања могу обезбедити брзи финансијски успех. Испоставило се да су трошкови превођења у електронски формат много већи него што се 90 -их уопште могло претпоставити, тако да је зарада у много случајева једва успевала да покрије трошкове. Све у свему, преовладало је уверење да ће у догледној будућности штампана књига остати главни извор профита.

10 Thompson, J. B. (2005) Books in the Digital Age, Cambridge: Polity, p. 310. 11 Исто, стр. 317. 


\section{СОЊА ОЦИЋ}

До драстичне промене у електронском издаваштву дошло је појавом Сонијевог читача у САД 2006. и Амазоновог Киндл читача 2007. и то је била трећа фаза у развоју електронског издаваштва. Већ током 2007, пре појаве Киндла 17. новембра 2007, продаја е-књига повећала се за 50 процената у односу на претходну годину, а када је Киндл постао доступан продаја је расла још драматичније - четири пута се увећала. Убрзан раст је настављен и наредне, 2009. године. Тај раст продаје е-књига тада још увек није био од великог значаја за америчке издавачке куће, јер је доносио само један проценат њихових укупних прихода. ${ }^{12}$

Ипак, значај појављивања Киндл читача на тржишту био је огроман. По мишљењу једног актера у издавачкој индустрији, на кога се позива Томпсон, после деценије разочаравајуће продаје електронских књига, Киндл је стимулисао продају таман толико да натера остале произвођаче хардвера да седну и обрате пажњу. ${ }^{13}$ Појава Киндл читача је уклонила неке од битних замерки електронској књизи, рецимо да није погодна за непрекидно дуже читање са компјутерског екрана и да је за приступ књизи потребна посебна опрема. Међутим, за разлику од екрана рачунара, екран електронског читача, киндла, чува вид. Корисници киндла као бројне позитивне стране овог читача наводе то да је лакши од мобилног телефона, у њега може стати око 35.000 књига, бежично учитавање појединачних наслова (куповина) траје око један минут, једноставан је за руковање, има опцију мењања типа слова и њихове величине, екран нема рефлексију, а цела справа је дебљине 3 мм и обима средње књиге. Преко Киндл читача могу се куповати књиге, новине и часописи. Екран је црно-бели. Може се користити око месец дана без пуњења батерије. Специјални екран који нема рефлексију, омогућава нам да без проблема читамо на сунцу или под било каквим осветљењем. Киндл памти страну на којој смо стали, има и опцију обележивача страна које су нам важне.

Број продатих електронских књига премашио је у фебруару 2011. године број штампаних књига, док је зарада од продаје електронских издања у Америци била преко 90 милиона долара, што је више него 200 посто раста у односу на фебруар 2010. године. У 2012. успех електронске књиге на тржишту се наставља, али 2013. поново долази до преокрета и то је последња фаза у развоју електронског издаваштва.

Током првих осам месеци 2013. године у Америци је повећана продаја штампаних књига у тврдом повезу за 10\%, а

12 Thompson, J. B. (2010) Merchants of Culture, Cambridge: Polity, p. 315

13 Исто, стр. 352. 
за то време продаја електронских књига, укључујући дечије и религиозне е-књиге, опала је за око 5\%. Ипак, упркос овом паду, постоје оцене да је 2013. била још једна узбудљива година за издавачку индустрију, можда најдинамичнија у историји издаваштва. Током 2013. сви издавачи е-издања повиновали су се контроли цена и цене е-књига су пале. У исто време, покренута је претплата на књиге. ${ }^{14}$

Као један од могућих разлога за опадање продаје е-књига аналитичари наводе недостатак бестселера на глобалном нивоу каквих је било претходних година. Порасту продаје е-књига током 2011. и 2012. године свакако су допринеле бестселер трилогије Педесет нијанси: сива и Игре глади. Ови наслови су се посебно добро продавали у електронском формату. Сада, када се више не налазе на топ листама, могућe je да су се читаоци вратили старим читалачким навикама узимања књига директно са полица пре него е-књига. ${ }^{15}$

Тренутно у САД е-књиге чине око $30 \%$ тржишта, а често и више од тога када је реч о популарној књижевности. Према организаторима овогодишњег Сајма књига у Франкфурту, у Европи је број купаца електронских књига нижи, износи око 5-7\%. Конкретно, према директору за дигиталне комуникације издавачке куће Макмилан, у Великој Британији само 4\% купаца књига одлучује се за е-књигу, већи проценат купује и штампане и електронске књиге, а највећи проценат и даље само штампане. ${ }^{16}$

У сваком случају, већина аналитичара се слаже да електронско издаваштво има неколико предности у односу на штампано. Ако би било потребно издвојити најважније од њих, то би биле економичност, хипертекстуалност, интерактивност и, као последица свега овога, демократичност. Размотрићемо сваку од ових предности појединачно.

Економичност - Електронско издаваштво штеди и време и новац, како произвођача тако и потрошача. Електронске публикације веома брзо настају и брзо се шире; када текст садржи HTML ознаке спреман је за објављивање. Друга ствар, ако је неопходно, електронски текст могуће је истог тренутка ажурирати и исправити, док штампана књига мора да чека друго издање. Нови подаци се било када могу додати у базе података које су увек доступне онлајн, а могу

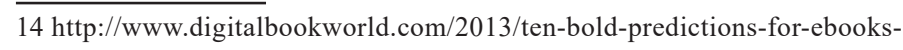
and-digital-publishing-in-2014/, приступљено 8.10.2014.

15 http://www.forbes.com/sites/jeremygreenfield/2013/11/19/hardcover-salesgrowth-outpacing-ebooks-in-2013/, приступљено 8.10.2014.

16 english.cntv.cn/2014/10/11/VIDE1412963303748176.shtm/, приступљено 15.10.2014. 


\section{СОЊА ОЦИЋ}

се ажурирати и подаци дати на ЦД-у, преко „апдејтова”, пише фон Луцијус. ${ }^{17}$ Такође, електронска издања је могуће дистрибуирати широм света без трошкова дистрибуције и поновног штампања и без потребе за преговарањем о правима.

Главна предност дигиталног производа у односу на штампани је то што су трошкови умножавања сведени на минимум, а код онлајн производа могу бити једнаки нули. Како нема трошкова штампе, е-издаваштво читаоцима доноси ниже цене књига док ауторима исплаћује веће хонораре. Амазон је тек изашлу биографију Стива Џобса у штампаном издању продавао за скоро 18 долара, док је цена електронске верзије износила 11,99 долара. ${ }^{18}$

Хипертекстуалност - Под хипертекстом се подразумева међусобно повезана нарација или информације. За разлику од штампане књиге која је одређена ограничењима три физичке димензије, у дигиталном свету „у једну идеју или ток мисли може се укључити мултидимензионална мрежа знакова ка даљим елаборатима или аргументима, који могу бити позвани или игнорисани." ${ }^{\prime 9}$ Реч је о колекцији еластичних порука које се могу раширити и скупити према читаочевим акцијама.

Интерактивност - Битна последица преласка на дигитално издаваштво јесте додатак графичких, аудио и видео елемената писаној речи. Због тога дигитални производи и носе назив мултимедија. Међутим, битно својство мултимедијских производа је њихова интерактивност, а то се односи искључиво на дигиталне производе. ${ }^{20}$ Електронско издање може бити резултат сарадње и интеракције неколико аутора или аутора и читалаца. Електронско издаваштво отвара нове могућности за кориснике, као и за ауторе и издаваче. Многи сајтови са електронским књигама или сајтови електронских издавача дозвољавају бесплатан приступ и охрабрују читаоце да упуте повратну реакцију на дело, често директно аутору, а не издавачу. ${ }^{21}$

Према Софронијевићу интерактивност је значајна предност електронске књиге. Традиционално читање подразумева усамљеног читаоца који је пасивни конзумент садржаја. Он

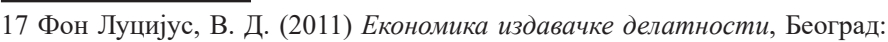
Клио, стр. 308.

18 http://www.politika.rs/rubrike/spektar/zivot-i-stil/Srpske-price-ilegalno-nakindlu.sr.html, приступљено 14. 11. 2011.

19 Негропонт, Н. (1998) Бити дигиталан, Београд: Клио, стр. 71.

20 Исто.

21 http://www.clio.rs/b-plus/elektr_izdavastvo.htm, приступљено 14. 11. 2011. 
води дијалог са аутором дела преко садржаја дела које представља медијум комуникације. Овакав дијалог није интерактиван пошто аутор није у могућности да дело освежава. У односу на Усамљеног читаоца, читање 2.0 карактеришу интерактивност и сарадња. ${ }^{22}$ Интерактивност у читању се реализује кроз допуну садржаја преко форми као што су забелешке и дописивање. Сарадња се остварује препоручивањем садржаја и креирањем додатних садржаја. Препоручивање садржаја обухвата оцене, обележавање делова текста, информацију о броју читалаца одређеног дела, док додатне садржаје налазимо у форми рецензија и дискусија.

Демократичност - Интерактивност као и хипертекстуалност обезбеђује још једну предност електронског издаваштва, а то је већа демократичност. Од повећане демократичности немају користи само читаоци који могу да изнесу свој суд о делу и поделе га са другим читаоцима, већ и сами писци. Електронско издаваштво пружило је могућност писцима који на други начин можда не би успели да изложе свој рад широј јавности, или који не би добили прилику да штампају своја дела кроз традиционалне канале којима господари главни ток штампаног издаваштва. Тако, на пример, Амазон пружа сваком могућност да се појави у највећој књижари на свету као независни аутор; потребно је само послати књигу у ворд формату, залепити цену по жељи, а Амазон ће се побринути за све остало.

У дебати о електронском издаваштву, посебан проблем је то што оно што је за неке предност електронске књиге у односу на штампану, за друге је недостатак. Шери Теркл (Sherry Turkle) сматра да наши уобичајени наративи о технологији почињу учтивим ниподаштавањем онога што је било раније и настављају се идеализацијом новог. Онлајн читање, са могућностима које пружају линкови и хипертекст, често добија херојски тријумфалистички наратив, док се књига омаловажава као „дисконектована”. Тај наратив иде отприлике овако, пише Теркл: „старо читање било је линеарно и искључиво; ново читање је демократско јер се сваки текст отвара према ланцу нових идеја.” Али, ово је само једна прича, сматра Теркл, прича коју технологија жели да исприча. „Постоји још једна прича. Књига је повезана са сањарењем и личним асоцијацијама јер су читаоци загледани у себе. Онлајн читање вас увек зове другде и оно је само понекад прекинуто улажењем на линк ради дела на које реферира и асоцираних коментара. Много је чешће прекинуто слањем

22 Софронијевић, А. (2010) Нова парадигма сарадње у библиотекама: више од шеб 2.0 технологија, Култура бр.129, Београд: Завод за проучавање културног развитка, стр. 57. 


\section{СОЊА ОЦИЋ}

порука, куповином, Фејсбуком, Мајспејсом и Јутјубом. Ова друга прича је сложена и људска. Али она није део тријумфалистичког наратива у ком свака нова технолошка могућност само пружа прилику, а никад не подилази рањивости и никад не ствара анксиозност." 23

Развој ситуације на тржишту дао је за право дигиталним скептицима који су остали привржени традиционалној штампаној књизи ценећи њену материјалност и смисленост и сумњајући да ће икада бити суштински замењена електронским фајловима који се читају на екрану. Књига је естетски пријатна форма, уметничко дело са стилизованом насловном страном и атрактивним дизајном, и право је задовољство имати је у рукама, отворити и поседовати. Она је изузетно пријатељски настројена према читаоцу: ништа није лакше него окретати странице књиге и читати чисти црни текст на белом папиру. Не напрежете очи и са лакоћом се можете кретати кроз књигу. Батерије се никада неће истрошити и књига се неће поломити ако је испустите. Штавише, књига је друштвени објекат: можете је делити са другима, позајмљивати и враћати, богатити своју колекцију, показивати на полици, пазити као нешто вредно и на основу ње стећи представу о њеном власнику и колико она њему значи; књига је симбол његовог идентитета. Дигитални скептици истичу да електронска књига не нуди ништа од овога.

На аргумент дигиталних оптимиста да ће се у издавачкој индустрији догодити оно што се већ догодило у музичкој индустрији, дигитални скептици тврде да се музика не може поредити са књигом. То што можемо своју музичку библиотеку да носимо са собом, кажу они, и да слушамо шта год пожелимо, заиста има бројне предности у односу на винилске плоче, па чак и у односу на касете, али је аналогија са књигом погрешна. Књига већ јесте носива, а чак и када је реч о људима који доста времена проводе у путовањима или одлазе на дуге одморе, једна књига ће им бити сасвим довољна.

Један од дигиталних скептика, чије мишљење Томпсон наводи, каже како он познаје мало људи који би желели да са собом носе 80 књига и да дигитални читачи нису за оне који желе да се удубе у књигу. Електронско издаваштво, по његовом мишљењу, никада неће бити велики бизнис. То није музички бизнис - то нису песме које трају два или три минута. То није бизнис дневних новина - књиге не стоје на полицама један дан или један сат. То није бизнис магазина

23 Теркл, Ш. (2011) Сами заједно, Београд: Клио, стр. 329. 


\section{СОЊА ОЦИЋ}

са садржајем кроз који можете проћи за време вожње подземном железницом. ${ }^{24}$

Томпсон такође сматра да постоје различити разлози због којих већина читалаца остаје дубоко везана за физичку књигу, не само зато што их спутавају техничке карактеристике електронских справа за читање, већ због тога што дају предност књизи као физичком и културном артефакту и верују да за одређени читалачки доживљај штампана књига има вредност коју електронске справе за читање, колико год биле развијене, не могу имати.

Многи аутори такође праве разлику између традиционалног и е-читања. Сматрају да је у традиционалном читању постојао елемент утехе, повлачења у благословену усамљеност; постојао је, како Барт пише, онај тренутак поистовећивања са „заљубљеним субјектом и мистичним субјектом“. $\mathrm{Ca}$ е-читањем то се губи и све је мање онога што се некада звало библиотерапија. ${ }^{25}$ Традиционалисти упозоравају на техничке и емоционалне недостатке е-читача: немате осећај докле сте стигли са читањем, не постоји мирис нити додир књиге, не постоје трагови ранијих читања.

Као предност штампане књиге над електронском многи наводе њену присност. Док читамо књигу као да смо у непосредном додиру са писцем, док слова на екрану делују некако ван нас. На тај начин размишља и Жан Филип де Тонак када одговара на питање шта ћемо изгубити са појавом тих нових, малих књига. „Неке застареле навике, можда. Извесну сакралност придавану књизи унутар једне цивилизације која ју је уздигла на пиједестал. Онај специфичан вид присности између писца и његовог читаоца коме ће појава хипертекстуалности неминовно наудити." 26

Предвиђања да ће са појавом електронске књиге нестати класична књига изазивала су углавном забринутост. Али има и оних који на прелаз од класичне ка електронској књизи гледају као на само још једну у низу промена какве су се одувек дешавале и на које се обично није гледало са одобравањем. Како тврди Вучковић, није реч ни о каквој новој појави. Људе је увек бринуо нестанак оног добро познатог. Тако у Платоновом дијалогу Федар, написаном пре близу 2.500 година, Сократ критикује проналазак писма сматрајући да

24 Исто, стр. 320.

25 Ковачевић, Н. (2010) О могућности и стварности - једно (не)аристотеловско читање е-књига, Култура бр. 129, Београд: Завод за проучавање културног развитка, стр. 31

26 Каријер, Ж. и Еко, У. (2011) Не надајте се да ћете се решити књига, Чачак: Градац К., стр. 7. 


\section{СОЊА ОЦИЋ}

оно носи привидну, а не стварну мудрост. Исто тако проналазак штампе проглашаван је непотребним и ђаволским изумом. Данас смо у средишту сличне полемике између заговорника Гутенбергове цивилизације књиге и поклоника Интернета и дигиталних комуникација. ${ }^{27}$

$$
* * *
$$

На крају, преостаје нам да одговоримо на два основна питања. Прво је да ли се дигитална револуција уопште догодила ако већ електронска књига није истиснула штампану? Друго питање гласи: да ли је штампана књига само један медиј између многих, од који сваки има своје предности и недостатке? Да ли је битан само садржај, прича или је битна и форма, односно медиј? Да ли су у праву Каријер и Еко (Jean-Claude Carrière, Umberto Eco) који су утешно поручивали: Не надајте се да ћете се решити књига. Књига је савршен изум, као точак, који се не може учинити бољим. ${ }^{28}$

Томпсон сматра да се у издавачкој индустрији догодила дигитална револуција, једино што то није баш онаква револуција какву су имали на уму рани заговорници е-књиге. Они су мислили да револуција мора да значи револущију у производу: што би значило да ће књига као физички објект нестати и да ће бити замењена нематеријалним садржајем који се може продати и купити. Међутим, сматра Томпсон, пре се ради о револуцији у процесу, него о револуцији у производу. Та револуција у процесу је оно што Томпсон назива скривеном револуцијом. ${ }^{29}$ То је револуција која се свакако догодила, и то у четири области: прва је оперативни систем, друга штампање, трећа продаја и маркетинг и четврта област је испорука садржаја.

Као и у многим секторима индустрије, и у издавачкој индустрији је извршена компјутеризација и дигитализација канцеларија и оперативних система. Документи, укључујући рукописе, циркулишу као електронски фајлови а не више као одштампани текстови. Што се штампања тиче, два сервиса су од посебног значаја: $S R D P^{30}$ и $P O D .^{31} S R D P$ се користи за штампање мањих количина примерака - од 10/20

27 Вучковић, Ж. Залазак Гутенбергове галаксије: Културолошке и епистемолошке импликације, http://teme.junis.ni.ac.rs/teme2-2011/teme\%20 2-2011-10.pdf, приступљено 10. 12. 2011.

28 Каријер, Ж. и Еко, У. (2011) Не надајте се да ћете се решити књига, Чачак: Градац К., стр. 15.

29 Thompson, J. B. (2010) Merchants of Culture, Cambridge: Polity, p. 321.

30 short-run digital printing.

31 printing on demand. 
до 300/400, и то је истовремено главна предност у односу на традиционалну, офсет штампу која је била економична само код већих тиража. POD је, међутим, нешто сасвим ново. Књиге су се раније прво штампале па продавале, сада се, захваљујући овом сервису прво продају па онда штампају. Једна од значајних предности ових нових могућности је то што су оне удахнуле нови живот бројним књигама које су препуштене забораву пре много година, јер нису могле бити штампане у новим, бројним тиражима које је, да би се то исплатило, захтевала традиционална штампа.

Дигитална револуција има велики утицај и на продају и на маркетинг. Драматичан успон Амазона најочигледнији је пример како је Интернет трансформисао продају књига на мало. Амазон је унео нешто потпуно ново у ову област: видљивост, расположивост и продаја књига постали су много мање зависни од одлука и интеракција у ланцу продаје књига, нарочито од одлука агената за трговину и других у издавачким кућама који одлучују о томе које ће књиге као приоритети бити понуђене књижарама, као и од одлука књижара које ће књиге складиштити и у којим количинама, како ће их изложити и слично.

Такође, дигитална револуција је променила правила игре у издаваштву учинивши бројке транспарентним. Нико више не може да крије или преувеличава успех претходне књиге, јер свако може да провери бројке. С друге стране, пише Томпсон, револуција е-маркетинга у издаваштву управо почиње. Све већа средства намењена маркетингу повлаче се из традиционалних штампаних медија и улажу у различите врсте онлајн маркетинга; издавачи све више користе Интернет да би ступили у директну везу са потрошачима и олакшали онлајн интеракцију између писца и читаоца. ${ }^{33}$

Други аспект маркетинга и промоције који је врло важан за издаваче је оно што би се могло назвати дигитално прелиставање. Наравно, увек је било могуће прелистати књигу пре него што је купимо, па и прочитати неколико страна. Али, издавачи сада могу понудити много више од онога што је било могуће у књижарама од цигли и малтера. Читаоци сада могу да прегледају садржај, да прочитају текст на омоту књиге, или чак да прочитају поглавље или два.

Утицај дигиталне револуције највећи је приликом испоруке садржаја. Садржај књиге одвојив је од њене форме. Ова 


\section{СОЊА ОЦИЋ}

карактеристика повезује књигу са другим производима медија и креативних индустрија, као што су филм, музика, новине, и то је разлог што је утицај дигиталне револуције у овим индустријама много већи него када је реч о, рецимо, индустрији фрижидера. У суштини, дигитализација садржаја раздваја садржај и форму. Стварна вредност књиге је у садржају и стога је слоган који се често понавља, а повезан је са дигиталном револуцијом, „садржај је краљ”.

Овде можемо да поставимо наше друго питање: да ли је „садржај краљ“?

Многи сматрају да је суштина књиге у снази речи и поруке коју она носи, без обзира на то да ли се она појављује у класичном или електронском лику. Добра књига је увек дијалог, трајна и неограничена међуљудска комуникација. Уместо било какве одбране књиге, довољно је да она буде прочитана, без обзира на то да ли је њен садржај на хартији или на екрану. ${ }^{34}$ Према Вучковићу, дилема класична или електронска књига је заправо лажна и резултат наше склоности да се стално опредељујемо и расправљамо по систему „или-или”. Треба да постоје и једна и друга и да обе имају своје предности и недостатке.

Ова иста страна у даљој аргументацији наводи да за издаваче и ауторе није најважније такмичење између електронских и традиционалних књига, већ колико времена су људи вољни да посвете читању, а не другим врстама забаве које им се нуде. ${ }^{35}$ Оно што је читаоцима важно јесте сама прича, тврди директор овогодишњег Сајма књига у Франкфурту, није битно да ли је одштампана или је дигитална, да ли је видео или холивудски филм, битна је прича.

Други, опет, сматрају да је битан формат, односно да различити формати одговарају различитим садржајима и различитим ситуацијама.

Електронски формат је свакако погодан за неке врсте књига, али не и за жанрове као што је књижевност; одговара одређеним приликама за читање, као што је путовање авионом, а мање одговара другим ситуацијама, нпр. док лежимо на каучу код куће. У том смислу може се испоставити да је е-књига пре допуна штампаној, као што су то дуго биле аудиокњиге, него њена замена. Може се десити да за 30 година књига

34 Вучковић, Ж. Залазак Гутенбергове галаксије: Културолошке и епистемолошке импликације, http://teme.junis.ni.ac.rs/teme2-2011/teme\%20 2-2011-10.pdf, приступљено 10.12.2011.

35 http://www.washingtonpost.com/blogs/wonkblog/wp/2013/08/08/e-book-sales-are-leveling-off-heres-why/, приступљено 8. 10. 2014. 
у старом облику, на папиру, уђе у елитну културу а да е-књига постане део масовне културе, као што је то пре 30 година била штампана књига. Тако су сада део елитне културе графички принтови који се штампају у ограниченом броју примерака и потписани су од стране аутора -графичара.

Трећи су, пак, они који тврде да је огромна предност штампане књиге управо то што су у њој садржај и форма неодвојиви; та јединствена комбинација је оно што читаоци цене и да она има све напред наведене предности. Електронска књига је пуки садржај и никада не може да репродукује материјалност штампане књиге.

Али, чак ни најватренији заговорници електронске књиге нису тврдили да ће књиге престати да се штампају. Електронска књига неће убити штампану књигу, као што ни изум телевизије није убио радио или као што DVD није убио телевизију. Има књига које су права уметничка дела и која ћете увек хтети да имате у штампаној форми... Али љубиће? Да ли бисте заиста желели да убијете дрво због њих ${ }^{36}$ Нема разлога да се са овим не сложимо.

\section{ЛИТЕРАТУРА:}

Барбије, Ф. (2009) Историја књиге, Београд: Народна библиотека Србије и Клио.

Гир, Ч. (2011) Дигитална култура, Београд: Клио.

Каријер, Ж. и Еко, У. (2011) Не надајте се да ћете се решити кљига, Чачак: Градац К.

Ковачевић, Н. (2010) О могућности и стварности - једно (не)аристотеловско читање е-књига, Култура бр. 129, Београд: Завод за проучавање културног развитка.

Фон Луцијус, В. Д. (2011) Економика издавачке делатности, Београд: Клио.

Негропонт, Н. (1998) Бити дигиталан, Београд: Клио.

Софронијевић, А. (2010) Нова парадигма сарадње у библиотекама: више од шеб 2.0 технологија, Култура бр. 129, Београд: Завод за проучавање културног развитка.

Thompson, J. B. (2005) Books in the Digital Age, Cambridge: Polity.

Thompson, J. B. (2010) Merchants of Culture, Cambridge: Polity.

Теркл, Ш. (2011) Сами заједно, Београд: Клио.

Угричић, С. (2010) Адаптација, еволуција, револуција, Култура бр. 129, Београд: Завод за проучавање културног развитка.

36 Thompson, J. B. (2010) Merchants of Culture, Cambridge: Polity, p. 354. 


\title{
СОњА ОЦИЋ
}

\section{Интернет линкови:}

http://www.digitalbookworld.com/2013/ten-bold-predictions-for-ebooks-and-digital-publishing-in-2014/

http://www.forbes.com/sites/jeremygreenfield/2013/11/19/hardcoversales-growth-outpacing-ebooks-in-2013/

english.cntv.cn/2014/10/11/VIDE1412963303748176.shtm/

http://www.politika.rs/rubrike/spektar/zivot-i-stil/Srpske-price-ilegalno-na-kindlu.sr.html

http://www.clio.rs/b-plus/elektr_izdavastvo.htm

http://www.washingtonpost.com/blogs/wonkblog/wp/2013/08/08/ebook-sales-are-leveling-off-heres-why/

Vučković, Ž. Zalazak Gutenbergove galaksije: Kulturološke i epistemološke implikacije, http://teme.junis.ni.ac.rs/teme2-2011/teme\%20 2-2011-10.pdf

\section{Sonja Ocić}

University in Belgrade, Faculty of Political Sciences, Belgrade

\section{E-BOOK}

\begin{abstract}
Unlike many texts written in the past two decades about the end of the printed book, this paper deals with the end of e-books. The latest reports of big losses in electronic publishing show that printed books have taken precedence again, which seems to hold ground. However, ups and downs in e-publishing have been happening before: the initial optimism from the beginning of the 90 s has been replaced by serious doubts, followed by launching of the Kindl reader that gave e-books precedence over printed versions. In contrast to this rather unstable situation on the market, the appearance of e-books has caused more controversy and future predictions than any other new medium before them. Many have predicted the end to the printed books and thus the end to an entire civilization, others have announced digital culture as a whole new way of life. Only some of them hesitated to call the changes revolutionary and most agreed that e-books have many advantages over the printed ones. Will anyone dare to predict anything now?
\end{abstract}

Key words: e-book, electronic publishing, printed book, John Thompson 